\title{
Nutrient chemistry and seasonal variation in the groundwater quality of a Riverine Island on the west coast of Kerala, India
}

\author{
P. J. Sajil Kumar' ${ }^{1}$ - Aswin Kokkat ${ }^{2}$ ·P. K. Kurian ${ }^{3}$ - E. J. James²
}

Received: 11 September 2016 / Accepted: 11 January 2020 / Published online: 24 January 2020

(c) The Author(s) 2020, corrected publication 2021

\begin{abstract}
This study attempted to evaluate the groundwater quality, with a special emphasis on nutrients, of a riverine coastal island near Kodungallur, Kerala. Water quality parameters were analyzed in the collected samples over pre- and post-monsoon seasons. A considerable variation in groundwater chemistry was observed in the two periods. During pre-monsoon season, many wells were contaminated with $\mathrm{TDS}, \mathrm{Cl}, \mathrm{Fe}, \mathrm{Ca}$ and $\mathrm{Mg}$ in certain locations. Whereas, post-monsoon water was relatively fresh, indicating the dilution process as well as aquifer recharge by the monsoon rain and consequent regression of saline water. A higher concentration of Fe was observed in the pre-monsoon season (41\%) than in the post-monsoon season (24\%). Nitrate and phosphates were analyzed to assess the nutrients and the observed concentration was below their corresponding permissible limits. Results show that overexploitation of the aquifer as well as the decreased flow of the River Periyar during the pre-monsoon period increased the threat from seawater intrusion and groundwater contamination. An interesting groundwater recharge mechanism locally known as backwashing - the diversion of rainwater from rooftops to dug wells-is being practiced in the study area and has been found to be effective in raising water levels and improving water quality.
\end{abstract}

Keywords Riverine Island · Groundwater · Water quality · Seasonal variation · Nutrient chemistry

\section{Introduction}

Water is the one of the sectors of the environment most affected by population growth. Extensive increase in surface water contamination observed in the last few decades indirectly exerted tremendous pressure on groundwater resources (Singh et al. 2007). In India, groundwater is the primary source of drinking and irrigation water (Suhag 2016). Naturally, the weathering of rocks, dissolution, deposition and evaporation are the major geochemical processes controlling the composition of groundwater. But in the present world, anthropogenic activities are more prominent than natural processes. Since groundwater quality assessment is important in deciding its utility, numerous studies were

P. J. Sajil Kumar

pjsajil@gmail.com; pj.sajil@fu-berlin.de

1 Hydrogeology Group, Institute of Geological Sciences, Freie Universität Berlin, 12249 Berlin, Germany

2 Water Institute, Karunya University, Coimbatore 641114 , India

3 Department of Extension and Continuing Education, Karunya University, Coimbatore 641114, India carried out in this field. However, a holistic approach taking into account both natural and anthropogenic influences on groundwater has become a necessity.

Groundwater in the islands has high significance because of its vulnerability to contamination. The first and foremost factor is the saline water intrusion due to the overexploitation of existing groundwater (Sajil Kumar 2016a, b). The island VP Thuruth is believed to have been formed in the great flood of $1341 \mathrm{AC}$ and located at the border of Ernakulam-Thrissur districts in Kerala (Kurian et al. 2011a, b). The area of VP Thuruth is 116 acres. From just 28 households in 1942, the riverine island has been experiencing migration, with 460 households today in the island, supporting a population of around 2000 people. The density of population is around $4400 / \mathrm{km}^{2}$, almost five times that of the state of Kerala. Today, the VP Thuruth is facing major issues with regards to the scarcity of good quality water for domestic use. The Kodungallur area shows the typical ridge and runnel topography with the ridges having greater thickness of coastal alluvium and the runnels having lesser thickness of sand. The area is affected by tidal influx and any attempt to draw more water, either by pumping or by deeper extraction, results in a salinity influx during the dry season. 
It is reported that $70 \%$ of the people in the Thrissur district depend on well water for their drinking water needs. The groundwater level is decreasing year by year and $70 \%$ of the wells dry up in summer. Tanker lorry water supply is costly but a growing business every year (Baby 2015). VP Thuruth is surrounded by the Periyar River, which is well connected to the Arabian Sea. Apart from the saline intrusion, poor sanitation and agriculture practices have added to the threats to the existing water quality. The most common contaminants that reach water resources from agricultural activities are nitrate, phosphate and potassium (Rajmohan and Elango 2005). As the study area is bounded by the river which is about to meet the Arabian sea, high saline river water is mixing with the groundwater in the VP Thuruth. Additionally, at the Estuarian environment, river carries high concentration of nutrients; thus, it has become a necessity for the community to evaluate the groundwater quality.

All over the world, the evaluation of groundwater quality is one of the most practiced methods to understand the quality of drinking water in an area. There are several studies that can be found in literature for the same (Singh et al. 2005; Subramani et al. 2005; Kumar et al. 2007; Papaioannoua et al, 2007; Nagarajan et al. 2010; Seckin et al, 2010;
Amoako et al. 2011; Vasanthavigar et al. 2012; Bouderbala 2015; Li et al. 2016; Singh et al. 2017). However, the assessment of the parameters included in each study is dependent on the environmental conditions, the expected contamination sources, determined by the preliminary survey, or by referral to earlier studies and of course the availability of analytical facilities within the economical scope of the study. Earlier studies in the VP Thuruth region suggested the possibility of saline intrusion and groundwater contamination (Kurian et al. 2011a, b). This area is surrounded by the Periyar River and thus forming an estuarian environment, which is often characterized by the accumulation of salts, metals and nutrients. Howarth (2002) reported that more than $60 \%$ of the coastal waters and estuaries in Unites States of America are severely contaminated by nutrient pollution. Similar observations were reported by Kumari et al. (2007) from Adimalathura and, Jayachandran et al. (2012), from Kodungallur Estuary.

Groundwater has always been hydrologically connected with the surface water and thus, there is an exchange of ions and nutrients from both sides. VP Thuruth is a sedimentary region where the hydraulic conductivity is higher than that of a hard rock region (Fig. 1). The nutrient chemistry of the

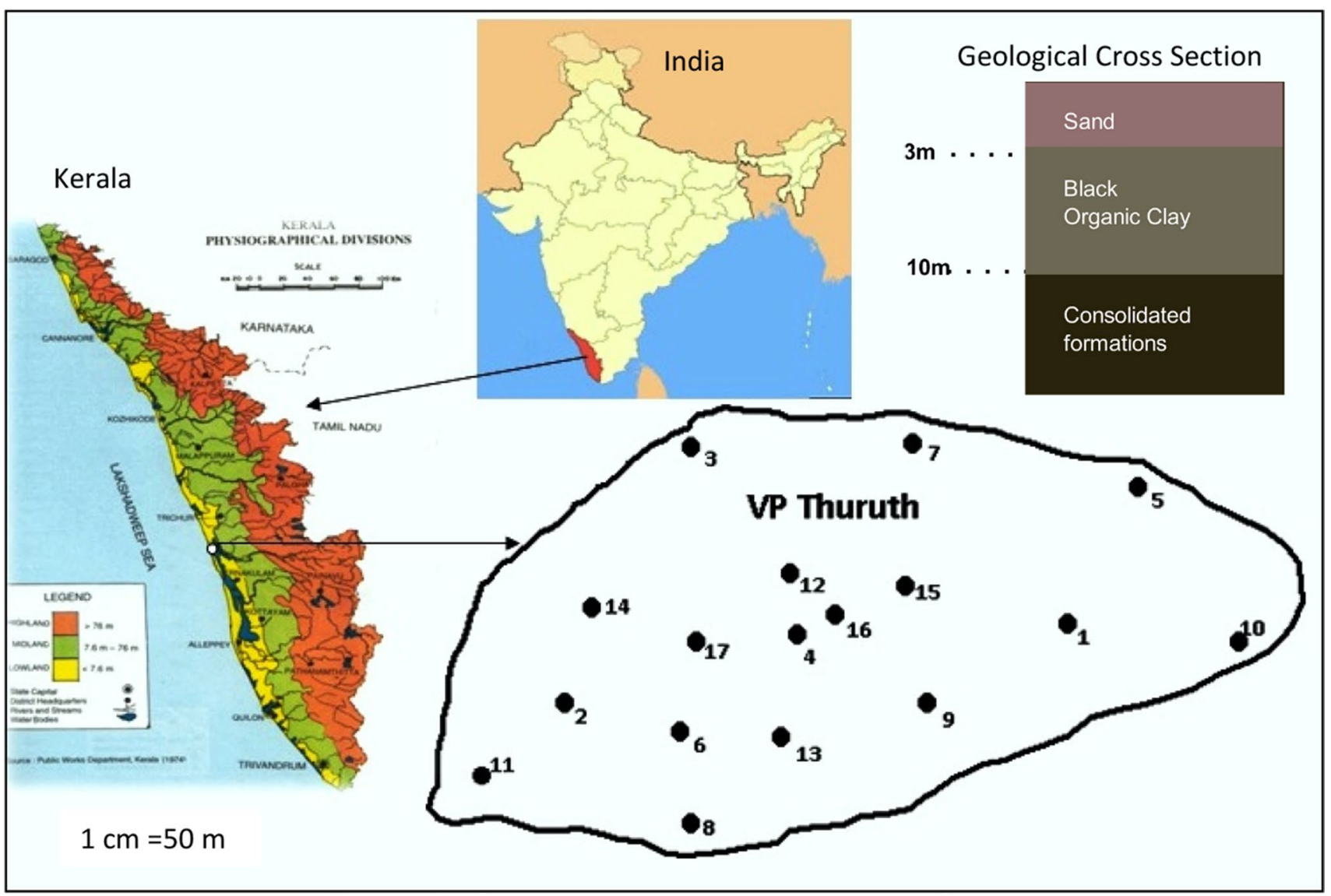

Fig. 1 Location map of VP Thuruth with sampling points 
Palar and Cheyyar River basins was studied by Rajmohan and Elango (2005). They found that agricultural activities, including the application of fertilizers, soil mineralization processes and irrigation return flow, are major processes controlling nutrient chemistry.

The aim of this study is to evaluate the groundwater quality in general and specifically the nutrient chemistry of the groundwater in VP Thuruth. This is a first kind of study on this topic and with the results we would like to make bench mark for the current water quality, which will be useful for the future studies and add information to the existing literature. If the quality of water found to be good, we will be advising the authorities to continue the current practices and in case contamination exists, we would like to suggest the possible mitigation measures for improving the groundwater quality.

\section{Study area}

VP Thuruth (Valiya Panickan Thuruth) is a riverine island located near Kodungallur in the Periyar River. The location and the geological cross section of the study area are presented in Fig. 1. Generally, the sand thickness near the coast is only $1-3 \mathrm{~m}$ and is underlain by black organic clay. Groundwater occurs under water table condition along the river courses, intermountain valleys and along the coastal plain. Dug wells are the common water development medium (CGWB 2008). The rainfall occurs more during southwest monsoon season (June-September) followed by northeast monsoon season (October-December). Annual rainfall numbers range between 2180.0 and $3484.0 \mathrm{~mm}$ with a mean of $2924 \mathrm{~mm}$. The temperature ranges from 22.1 to $36.2{ }^{\circ} \mathrm{C}$. The humidity is higher during monsoon months from June to October, and can reach around 93\% during morning hours and $76 \%$ during evening hours. Common soil types of the study area are coastal alluvium and riverine alluvium. Coastal alluvium is developed from recent marine deposits with a texture dominated by partially sorted sand fractions. The water holding capacity of these soils is low and they are excessively drained with very rapid permeability (Kurian et al. 2011a, b). Riverine alluvium consists of moderately well drainage system and is distributed mainly on the banks of rivers and their tributaries. These banks are light to medium textured with more than $65 \%$ sand, $15 \%$ clay, $20 \%$ of clay and contain organic matter, nitrogen and potash moderately. They show wide variations in their physicochemical properties, with a range in depth of 1-10 $\mathrm{m}$.

\section{Groundwater sampling and analysis}

We have selected 17 open wells covering the whole island for collecting groundwater samples. Samples were collected in pre-monsoon and post-monsoon seasons to understand the seasonal variation in the water quality. Groundwater samples were analyzed for temperature, $\mathrm{pH}$, total dissolved solids (TDS), $\mathrm{HCO}_{3}{ }^{-}, \mathrm{CO}_{3}{ }^{-}, \mathrm{Cl}^{-}, \mathrm{SO}_{4}{ }^{2-}, \mathrm{SO}_{4}, \mathrm{NO}_{3}, \mathrm{~F}$ and $\mathrm{PO}_{4}$ as per the standard methods suggested by APHA (1995). It is observed that the Ion Balance Error (IBE) values for all the samples were below $\pm 5 \%$. We have used both the World Health Organization (WHO 1993) and the Bureau of Indian Standards (BIS 1991) to understand the drinking water quality of the study area.

\section{Results and discussions}

\section{Groundwater quality and its seasonal variation}

Groundwater samples were analyzed for the pre-monsoon (April 2010) and post-monsoon (November 2010) seasons. In general, groundwater shows a wide variation in its chemical characteristics over the seasons. During April 2010 (summer), many samples exceeded the permissible limit of most water quality parameters. However, in November 2010 (winter), most of them were far below the maximum permissible limit suggested by World Health Organization (WHO) (1993) and BIS (1991). The improvement in groundwater quality can be attributed to the recharge from rainfall and artificial recharge practices. This resulted in two major processes in the groundwater environment, namely the dilution of high saline water and the pushing of the seawater-freshwater interface towards the coast. The other reason may be that the abundant flow in the Periyar River met the needs of the population and reduced the pressure on groundwater.

Though the majority of water samples are alkaline, a few samples showed a slightly acidic nature. This acidic nature was more prominent in the post-monsoon season (avg. 6.8), while pre-monsoon samples are dominated by alkaline water (avg. 7.73). The seasonal variation of $\mathrm{pH}$ is given in Fig. 2.

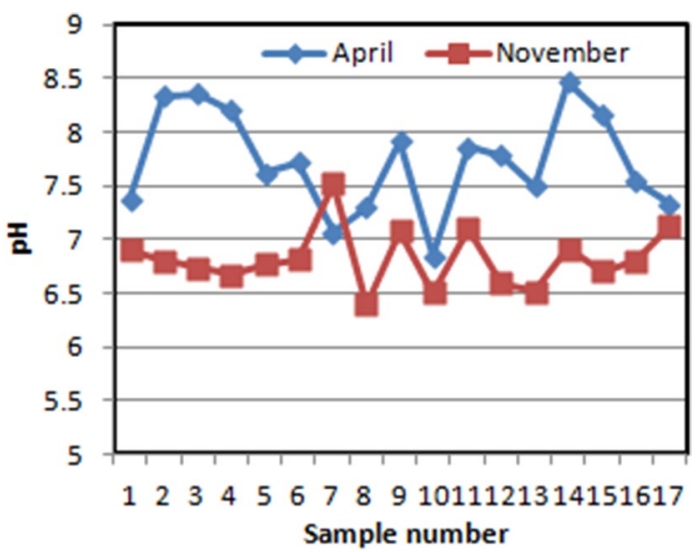

Fig. 2 Seasonal variation of $\mathrm{pH}$ 
However, in both seasons, water samples were within the permissible limit of 6.5-8.5 (World Health Organization (WHO) 1993). Electrical conductivity was used in the calculation of TDS, using the Equation TDS $=\mathrm{EC} \times 0.64$. In the present study, wells located near the coast showed a high concentration of EC. In the pre-monsoon season, 30\% of the samples exceeded the permissible limit of EC $(1500 \mu \mathrm{S} / \mathrm{cm})$ or TDS $(1000 \mathrm{mg} / \mathrm{l})$. The highest TDS value in this season is shown by the well No. 6. But in the post-monsoon season, all the samples were below the permissible limit. This may be due to the dilution of saline water with fresh water. The effectiveness of the recharge is supported by rooftop harvesting methods and consequent recharge of groundwater through dug wells. Heavy flow after rain in the Periyar is maintaining the pressure head around the island may prevent the runoff. The seasonal variation of TDS is given in Fig. 3.

Alkalinity is the measurement of all bases in water and represents the buffering capacity of water to neutralize an acid, mainly carbonate and bicarbonate concentrations in groundwater. However, hydroxides, silicate, borate, phosphate, acetate and propionate are the non-carbonate suppliers to the alkalinity of groundwater (Hem 1985). The alkalinity of the pre-monsoon season ranged between 58 and $178 \mathrm{mg} / 1$ with an average of $137 \mathrm{mg} / 1$; while in the post-monsoon season, it varied from 9 to $204 \mathrm{mg} / \mathrm{l}$ with an average of $85 \mathrm{mg} / \mathrm{l}$. Alkalinity of water is mainly controlled by the dissolution of carbonate minerals under lower $\mathrm{pH}$ conditions. An acidic $\mathrm{pH}$ in the post-monsoon season supports this argument. In the pre-monsoon season, the low flow rate and relatively high $\mathrm{pH}$ may lead to the precipitation of $\mathrm{CaCO}_{3}$. Acidity of the samples was relatively less, an average of $2.82 \mathrm{mg} / \mathrm{l}$ in the pre-monsoon season and $4.1 \mathrm{mg} / \mathrm{l}$ in the post-monsoon season. Variation in alkalinity and acidity over both seasons is given in Figs. 4 and 5, respectively.

Total hardness is an important parameter to determine the quality of water for drinking purposes. It is a measure of divalent cations in the water and the most common elements

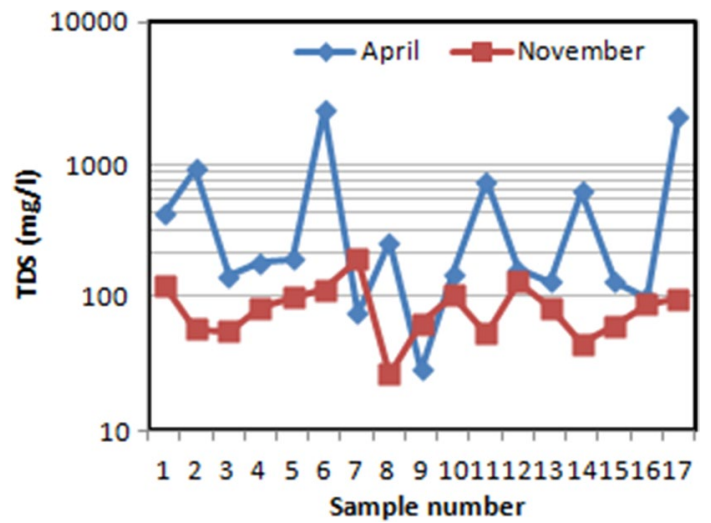

Fig. 3 Seasonal variation of TDS

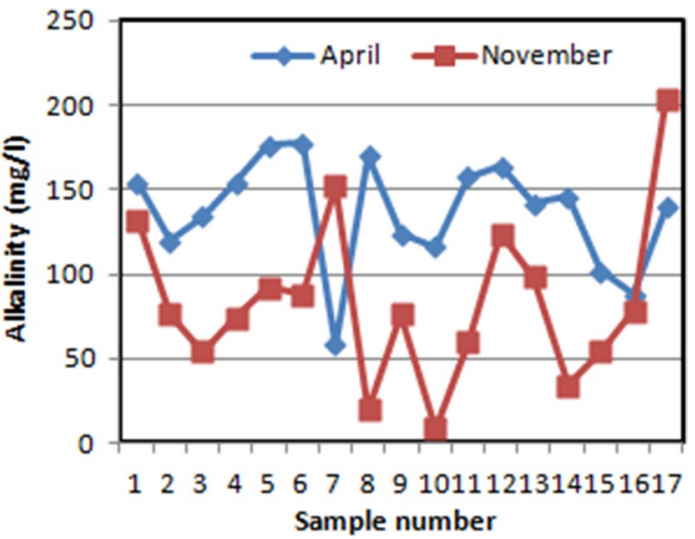

Fig. 4 Seasonal variation of alkalinity

are $\mathrm{Ca}^{2+}$ and $\mathrm{Mg}^{2+}$. In VP Thuruth, the majority of samples in the pre-monsoon season showed a hard type of water. Of the samples, $41 \%$ were above $300 \mathrm{mg} / \mathrm{l}$ and classified as very hard type, $18 \%$ were between 150 and $300 \mathrm{mg} / \mathrm{l}$ and classified as hard water, $23 \%$ were moderately hard and $19 \%$ were soft. The highest hardness was shown by the sample 6 . Additionally, well no. 17 also has hardness over $2000 \mathrm{mg} / \mathrm{L}$. In general, $59 \%$ of the water samples were either hard or very hard. Contrary to this, during post-monsoon season, except for $6 \%$ of the hard water samples, all the samples were under a good category. Variation in TH over the seasons is shown in Fig. 6.

Calcium and magnesium are responsible for the permanent hardness in groundwater. Mostly, these ions have geogenic origin through the dissolution of calcite, dolomite or the weathering of silicate minerals. The concentration of calcium during the pre-monsoon season varied between 5 and $592 \mathrm{mg} / \mathrm{l}$ with an average of $104 \mathrm{mg} / \mathrm{l}$ (Fig. 7). Results show that $30 \%$ of the samples exceeded the permissible limit of $75 \mathrm{mg} / \mathrm{l}$ (World Health Organization (WHO) 1993).

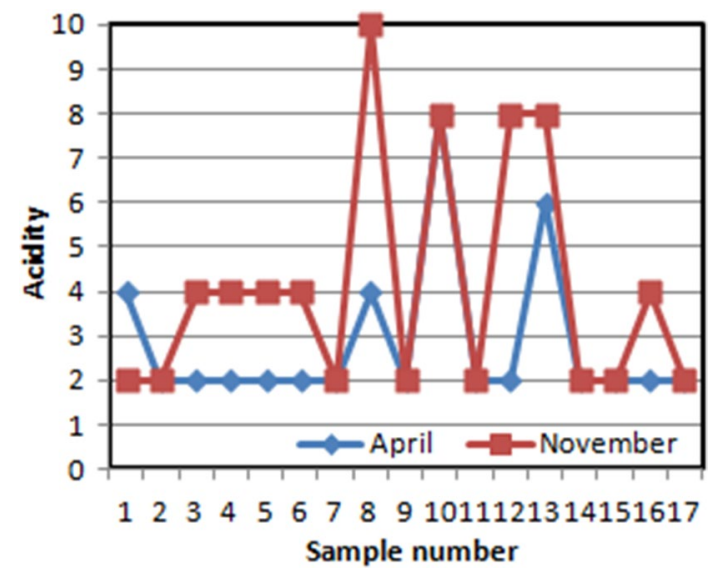

Fig. 5 Seasonal variation of acidity 


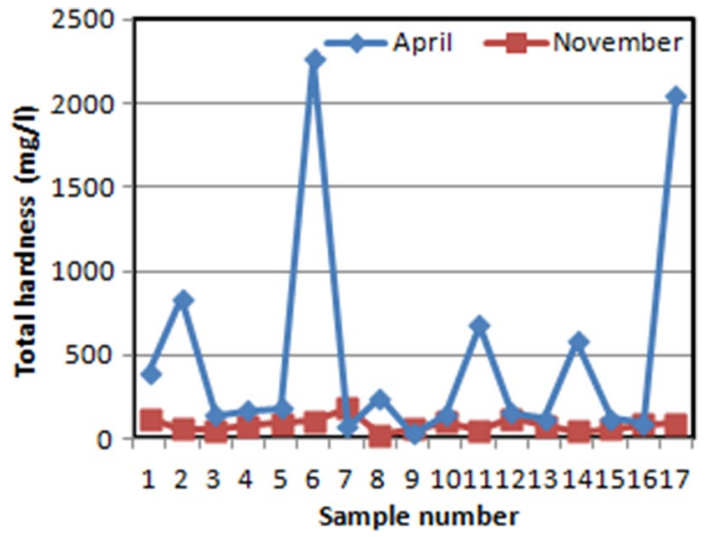

Fig. 6 Seasonal variation of TH

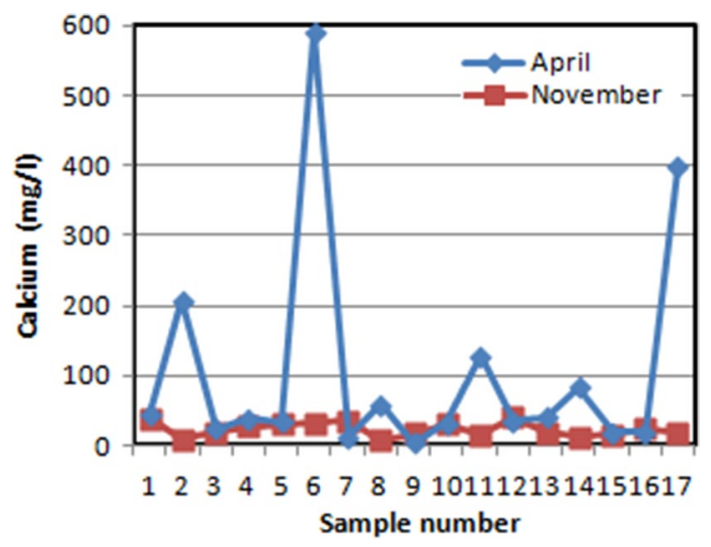

Fig. 7 Seasonal variation of $\mathrm{Ca}$

While, in the post-monsoon season, the range was $7-40 \mathrm{mg} / \mathrm{l}$ and all the samples were within the permissible limit. During pre-monsoon season, $35 \%$ of the magnesium samples were above the permissible limit of $50 \mathrm{mg} / \mathrm{l}$ (World Health Organization (WHO) 1993). The average concentration was $55 \mathrm{mg} / \mathrm{l}$. The maximum concentration in the post-monsoon season was $23 \mathrm{mg} / \mathrm{l}$, and it means that all samples were under the permissible limit (Fig. 8). The general trend in concentration of $\mathrm{Ca}$ and $\mathrm{Mg}$ is similar to the Total Hardness, as discussed in the earlier section.

Concentration of chloride in the pre-monsoon period was in the range of 32-6460 mg/l and in the post-monsoon period between 16 and $222 \mathrm{mg} / \mathrm{l}$. A high variation in concentration is visible over these seasons (Fig. 9). Of the premonsoon samples, $41 \%$ were above the permissible limit of $200 \mathrm{mg} / \mathrm{l}$, while only $6 \%$ from the post-monsoon season samples exceeded the limit. Very high concentration (>6000 mg/l) was observed in samples 6 and 17. Samples 11 and 14 have also concentration higher than $2000 \mathrm{mg} / \mathrm{L}$. In coastal aquifers, a major source of $\mathrm{Cl}$ is seawater intrusion. Domestic sewages have at least $50 \mathrm{mg} / \mathrm{l}$ of $\mathrm{Cl}$ more than that

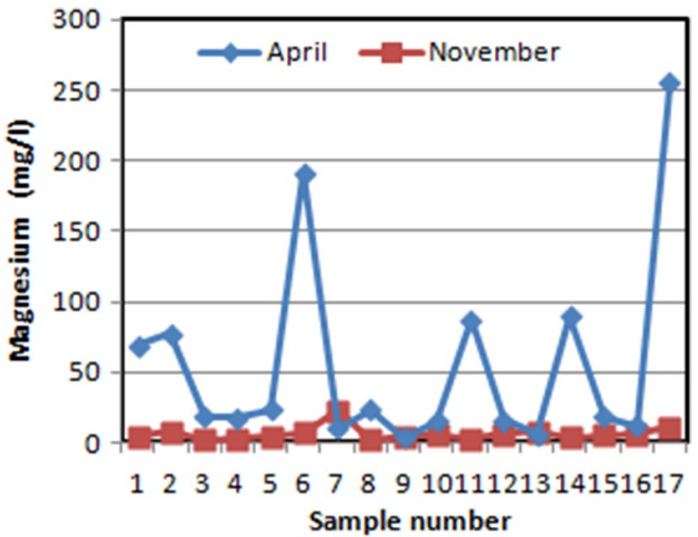

Fig. 8 Seasonal variation of $\mathrm{Mg}$

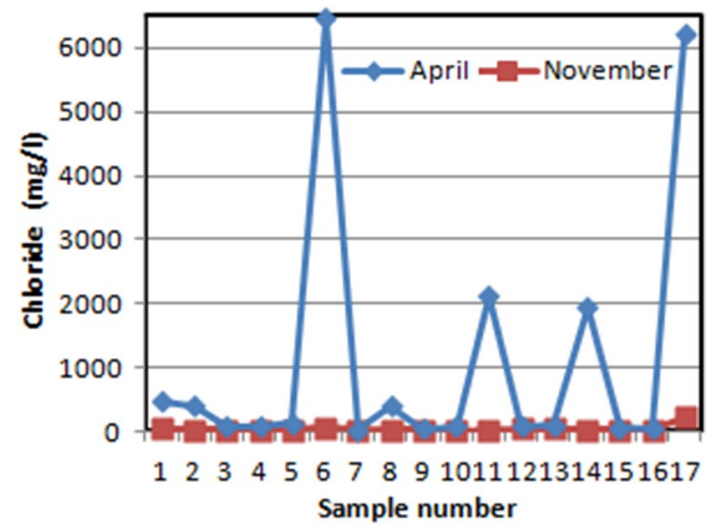

Fig. 9 Seasonal variation of $\mathrm{Cl}$

of normal water and are also contributing a considerable amount of $\mathrm{Cl}$ to the groundwater. Groundwater withdrawal from the wells is comparably higher in the pre-monsoon season than in the post-monsoon season. When the rate of withdrawal is higher than that of the recharge, the groundwater level will go down and the aquifers with this condition are known as over-exploited. This will result in the intrusion of seawater into the freshwater aquifers. The high concentration of $\mathrm{Cl}$ during the pre-monsoon period may be due to this phenomenon.

Sulfate in the study varied from 2.8 to $288 \mathrm{mg} / \mathrm{l}$, during pre-monsoon season and $2.7-38.4 \mathrm{mg} / \mathrm{l}$ during post-monsoon season (Fig. 10). 18\% of the samples (sample numbers 6, 11 and 17) from the pre-monsoon period exceeded the permissible limit of $200 \mathrm{mg} / \mathrm{l}$ (World Health Organization (WHO) 1993). All the samples in the post-monsoon season were below the permissible limit. The origin of most sulfate compounds is the oxidation of sulfide ores, the presence of shale, or industrial wastes. Dissolution of gypsum is also an important source in the present study area. 


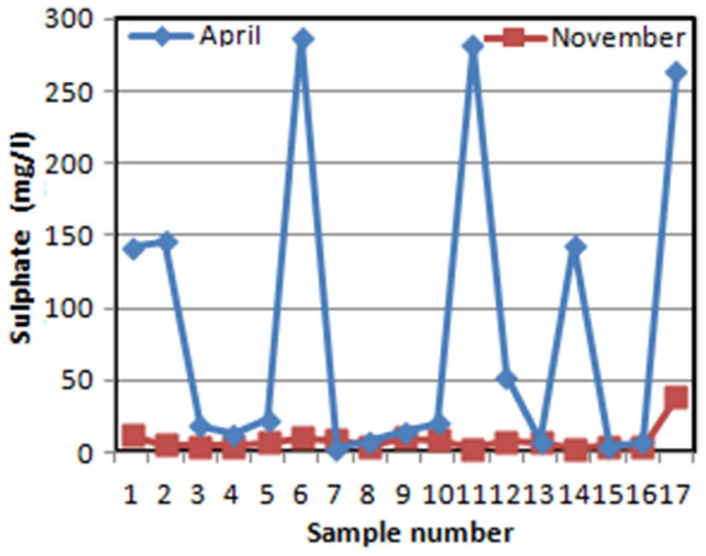

Fig. 10 Seasonal variation of $\mathrm{SO}_{4}$

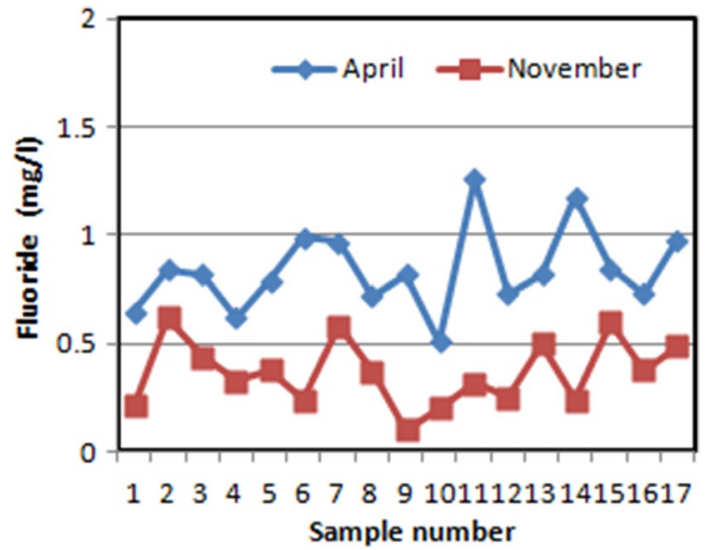

Fig. 11 Seasonal variation of $\mathrm{F}$

Fluoride is a minor ion which is good for dental and skeletal health under optimum consumption. However, a high concentration of $\mathrm{F}$ in drinking water can cause dental and skeletal fluorosis. According to WHO standards, the permissible limit is $1.5 \mathrm{mg} / \mathrm{l}$; in the present study, premonsoon samples showed higher concentration than the post-monsoon season (Fig. 11). However, all the samples in both seasons are within this permissible limit $1.5 \mathrm{mg} / \mathrm{l}$. Concentration of $\mathrm{Na}$, alkaline $\mathrm{pH}$, and bicarbonate will enhance the concentration of $\mathrm{F}$ in groundwater; whereas, $\mathrm{Ca}$ reduces $\mathrm{F}$ concentration by the precipitation of $\mathrm{CaF}_{2}$.

The concentration of iron was high in many samples. The permissible limit of $\mathrm{Fe}$ in drinking water is $1 \mathrm{mg} / \mathrm{l}$. The percentage of samples which exceeded the permissible limit during the pre-monsoon and post-monsoon period was $41 \%$ and $24 \%$, respectively (Fig. 12). Oxidation is the major process that controls the fate of iron in a groundwater environment. Aeration of iron-containing layers in the soil can affect the quality of both groundwater and surface water if the groundwater table is lowered. A lowering of the water table takes place during the summer seasons;

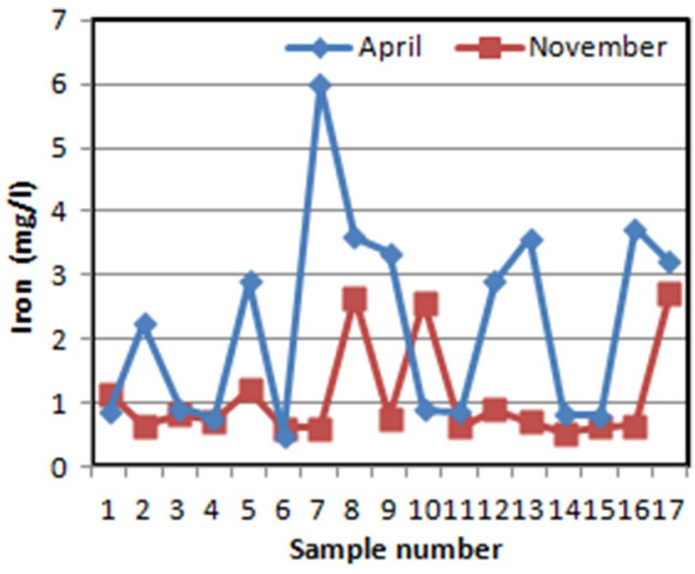

Fig. 12 Seasonal variation of Fe

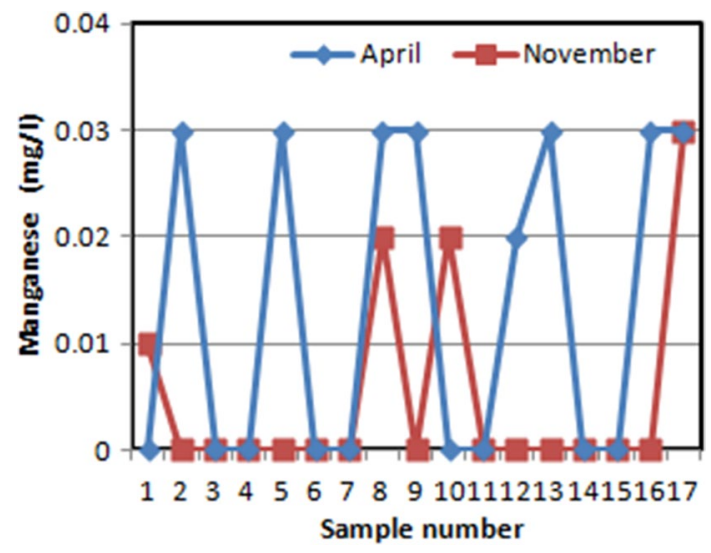

Fig. 13 Seasonal variation of $\mathrm{Mn}$

this may be a reason for the high concentration of iron in the pre-monsoon period. Concentration of manganese was well within the permissible limit of $0.5 \mathrm{mg} / \mathrm{l}$ in both seasons (Fig. 13).

\section{Nutrient chemistry}

The present study considered nitrate and phosphate to evaluate the nutrient chemistry. Nitrate is an important nutrient for plant growth and forms an essential part of the nitrogen cycle (WHO 2011). Both natural and anthropogenic sources of nitrate are present in groundwater, but the latter is predominant (Kumar et al. 2009a, b; Sajil Kumar et al. 2014; Rajmohan and Elango 2005). Groundwater contamination with nitrate is mainly caused by agricultural activities (fertilizers and manures), the leaching of natural vegetation and also improper sewage disposal containing human as well as animal excreta. The guideline value of nitrate in drinking water is $50 \mathrm{mg} / \mathrm{l}$ (WHO 2011). High consumption of nitrate causes methemoglobinemia, 


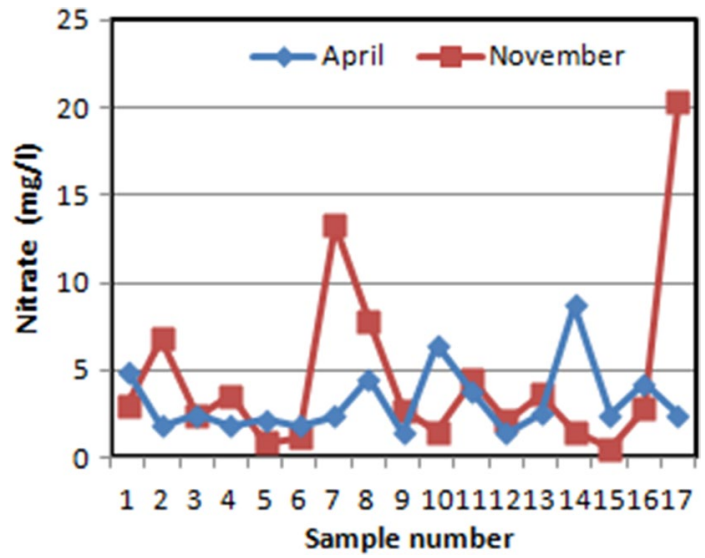

Fig. 14 Seasonal variation of $\mathrm{NO}_{3}$

a disease which prevents hemoglobin from releasing oxygen effectively to the body tissues. There are no known natural sources of nitrate reported or found from the study area. In VP Thuruth, a relatively lower concentration was found during the pre-monsoon period $(1.44-8.74 \mathrm{mg} / \mathrm{l})$. For the post-monsoon season, this number reached 0.49-20.33 mg/l (Fig. 14). Results showed that groundwater has a nitrate concentration below the maximum permissible limit in both seasons. During monsoon period, an increased recharge of groundwater in agricultural areas is observed, which can enhance the leaching of nitrate. The resulting increase in the water level causes the dissolution of nitrate in the capillary and Vadose zones and will also affect the nitrate concentration (Rajmohan and Elango 2005). However, the global natural background values of nitrate are estimated at $3 \mathrm{mg} / \mathrm{l}$ (Jacks and Sharma 1983). Any concentration level higher than this value in the study area is an indication of human activities such as fertilizer usage, soil nitrogen releases due to cultivation and domestic sewages. Similar observations were made by Babiker et al. (2004) and Nas and Berktay (2006).

Phosphates are an important nutrient to plants and animals. It is an essential constituent of fertilizers and may reach the groundwater by rainwater infiltration. The concentration of phosphate in groundwater is relatively less because of the retaining capacity of soil as well as the low solubility of this ion in water. Apart from fertilizers, it can enter into water resources in many ways such as phosphate-rich rocks, wastes from laundries, industrial processes and human and animal wastes. According to The Canadian Department of National Health and Welfare (1969), the permissible limit of phosphate in drinking water is $0.2 \mathrm{mg} / \mathrm{l}$. There are not many reports on the health hazards of phosphates. However, a higher concentration may interfere with digestion. In the study area, the concentration of phosphates ranged between 0.1 and $0.06 \mathrm{mg} / \mathrm{l}$, suggesting that the groundwater is well

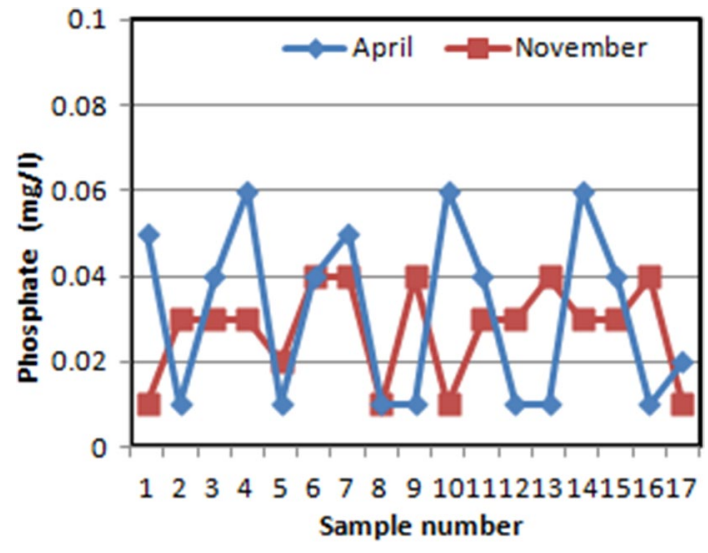

Fig. 15 Seasonal variation of $\mathrm{PO}_{4}$

within the permissible limit of phosphates. The seasonal variation of phosphate is given in Fig. 15.

\section{Conclusions}

Seasonal variation in the groundwater quality over the pre- and post-monsoon seasons is found to be significant in this study, especially in the samples 6,11,14 and 17 Total dissolves solids (TDS) showed considerably water quality changes, high salinity in the pre-monsoon (Avg. $=2142 \mathrm{mg} / \mathrm{l}$ ) compared to $212 \mathrm{mg} / \mathrm{l}$, in the post-monsoon season. Salinity ingression is identified as the reason for high salinity, resulted from overexploitation of groundwater to meet the increases demand for the domestic and irrigational purposes. Continuous usage of high saline water may cause high blood pressure, heart and kidney disease and dehydration in human beings. Total hardness, calcium, magnesium, chloride, sulfate, fluoride, nitrate, phosphate, iron and manganese have also showed similar changes over the seasons. Concentration of Fe exceeded the permissible limit in few wells. Excess intake of iron may cause gene mutation, liver, heart and pancreatic damage, as well as diabetes. The concentration of nitrate, manganese and phosphate were well within the limit in all the wells, suggesting that the agricultural activities did not affect the groundwater quality. Geologically, there is no fluoride in the study area, which is evident from the negligible concentration of $\mathrm{F}$ in the groundwater. Controlled use of groundwater and the promotion of artificial recharge and rainwater harvesting are coming up as the only logical solution for the water stress and quality issues in this area. There are initiatives from the state government to recharge the existing dug wells with a cost-effective recharge method called "backwashing", which is found to be very successful. This method can be extended to regions with similar hydrological-hydrogeological conditions elsewhere in the world. 
Funding Open Access funding enabled and organized by Projekt DEAL.

Open Access This article is licensed under a Creative Commons Attribution 4.0 International License, which permits use, sharing, adaptation, distribution and reproduction in any medium or format, as long as you give appropriate credit to the original author(s) and the source, provide a link to the Creative Commons licence, and indicate if changes were made. The images or other third party material in this article are included in the article's Creative Commons licence, unless indicated otherwise in a credit line to the material. If material is not included in the article's Creative Commons licence and your intended use is not permitted by statutory regulation or exceeds the permitted use, you will need to obtain permission directly from the copyright holder. To view a copy of this licence, visit http://creativecommons.org/licenses/by/4.0/.

\section{References}

Amoako J, Karikari AY, Ansa-Asare OD (2011) Physico-chemical quality of boreholes in Densu Basin of Ghana. Appl Water Sci $1: 41-48$

APHA (1995) Standard methods for estimation of water and waste water, 19th edn. American Public Health Association, Washington

Babiker IS, Mohamed AAM, Terao H, Kato K, Ohta K (2004) Assessment of groundwater contamination by nitrate leaching from intensive vegetable cultivation using geographical information system. Environ Int 29(8):1009-1017

Baby VK (2015) Water security-sanitation nexus: key to sustainable future-lessons from Kerala. Wash Summit India, India

BIS (Bureau of Indian Standards) 10500 (1991) Indian standard drinking water specification (1st revision)

Bouderbala A (2015) Assessment of groundwater quality and its suitability for agricultural uses in the Nador Plain, north of Algeria. Water Qual Expo Health 7:445-457

Canadian Department of National Health and Welfare (1969) Canadian drinking water standards and objectives, Canada

CGWB (2008) Groundwater information booklet, of Thrissur district, Kerala state, p 6

Hem JD (1985) Study and interpretation of the chemical characteristics of natural water, 3rd edn. US Geological Survey Water-Supply Paper 2254, University of Virginia, Charlottesville, 263 p

Howarth RW (2002) The nitrogen cycle. In: Mooney HA, Canadell $\mathrm{J}$ (eds) Encyclopedia of global environmental change, the earth system: biological and ecological dimensions of global environmental change, vol 2. Wiley, Chichester, pp 429-435

Jacks G, Sharma VP (1983) Nitrogen circulation and nitrate in groundwater in an agricultural catchment in southern India. Environ Geol 5:61-64

Jayachandran PR, Nandan SB, Sreedevi OK (2012) Water quality variation and nutrient characteristics of Kodungallur-Azhikode Estuary, Kerala, India. Ind J Geomar Sci 41:180-187

Kumar KSA, Azis PKA, Natarajan N (2007) Water quality of Adimalathura Estuary, Southwest coast of India. J Mar Biol Ass India 49:1-6

Kumar M, Sharma B, Ramanathan AL, Rao MS, Kumar B (2009a) Nutrient chemistry and salinity mapping of the Delhi aquifer, India: source identification perspective. Environ Geol 56:1171-1181

Kumar SK, Rammohan V, Sahayam DJ, Jeevanandam M (2009b) Assessment of groundwater quality and hydrogeochemistry of Manimuktha River basin, Tamil Nadu, India. Environ Monit Assess 159:341-351

Kurian PK, Sajil Kumar PJ, James EJ, Terry T (2011a) Backwashing of wells: a participatory water asset recovery method in the coastal areas of Kerala. World aqua congress, New Delhi
Kurian PK, Sajil Kumar PJ, James EJ, Thomas T (2011b) Backwashing of wells: a participatory asset recovery method in coastal areas of Kerala. In: Vth World aqua congress, vol 2

Li P, Li X, Meng X, Li M, Zhang Y (2016) Appraising groundwater quality and health risks from contamination in a semiarid region of northwest China. Expo Health 8(3):361-379

Nagarajan R, Rajmohan N, Mahendran U, Senthamilkumar S (2010) Evaluation of groundwater quality and its suitability for drinking and agricultural use in Thanjavur city, Tamil Nadu, India. Environ Monit Assess 171:289-308

Nas B, Berktay A (2006) Groundwater contamination by nitrates in the city of Konya, (Turkey): a GIS perspective. J Environ Manage 79(1):30-37

Papaioannoua A, Plagerasa P, Dovrikib E, Minasa A, Krikelisa V, Nastosc PT, Kakavasa K, Paliatsosd AG (2007) Groundwater quality and location of productive activities in the region of Thessaly (Greece). Desal 213:209-217

Rajmohan N, Elango L (2005) Nutrient chemistry of groundwater in an intensively irrigated region of Southern India. Environ Geol 47:820-830

Sajil Kumar PJ (2016a) Deciphering the groundwater-saline water interaction in a complex coastal aquifer in South India using statistical and hydrochemcial mixing models. Model Earth Syst Environ 2(4):194

Sajil Kumar PJ (2016b) Deciphering the groundwater-saline water interaction in a complex coastal aquifer in South India using statistical and hydrochemical mixing models. Model Earth Syst Environ 2:194. https://doi.org/10.1007/s40808-016-0251-2

Sajil Kumar PJ, Jegathambal P, James EJ (2014) Chemometric evaluation of nitrate contamination in the groundwater of a hard rock area in Dharapuram, south India. Appl Water Sci 4(4):397-405

Seckin G, Yilmaz T, Sari B, Ersu BC (2010) Groundwater hydrochemistry at the Mediterranean coastal plains-the case of Silifke, Turkey. Desalination 253:164-169

Singh KP, Malik A, Singh KV, Mohan D, Sinha Sarita (2005) Chemometric analysis of groundwater quality data of alluvial aquifer of Gangetic plain, North India. Anal Chim Acta 550:82-91

Singh KP, Malik A, Mohan D, Singh VK, Sinha S (2007) Evaluation of groundwater quality in Northern Indo-Gangetic Alluvium Region. Environ Monit Assess 112:211-230

Singh CK, Kumar A, Shashtri S, Kumar A, Kumar P, Mallick J (2017) Multivariate statistical analysis and geochemical modeling for geochemical assessment of groundwater of Delhi, India. J Geochem Explor 175:59-71

Subramani T, Elango L, Damodarasamy SR (2005) Groundwater quality and its suitability for drinking and agricultural use in Chithar River Basin, Tamil Nadu, India. Environ Geol 47:1099-1110

Suhag R (2016) Overview of ground water in India. Retrieved from http://www.prsindia.org/administrator/uploads/general/14556 82937 Overview\%20of\%20Ground\%20Water\%20in\%20India. pdf

Vasanthavigar M, Srinivasamoorthy K, Prasanna MV (2012) Evaluation of groundwater suitability for domestic, irrigational, and industrial purposes: a case study from Thirumanimuttar river basin, Tamil Nadu, India. Environ Monit Assess 184:405-420

WHO (2011) Guidelines for drinking-water quality, IV edn. World Health Organization, Geneva

World Health Organization (WHO) (1993) Guidelines for drinking water quality, vol 1, 2nd edn. World Health Organization, Geneva

Publisher's Note Springer Nature remains neutral with regard to jurisdictional claims in published maps and institutional affiliations. 